\title{
Asperger's syndrome: who is being abused?
}

\author{
M Perkins, S N Wolkind
}

\begin{abstract}
Six case histories of children referred and admitted to a psychiatric inpatient unit at a tertiary referral centre because of concerns about poor functioning and possible emotional abuse are presented. On initial assessment the children appeared to be well functioning and the impression was confirmed that their emotional needs were not being met by their parents. After detailed inpatient appraisal the diagnosis of Asperger's syndrome was made in all six cases, exemplified mainly by a formal concrete way of thinking and an inability to identify and understand human emotions and relationships. The impact of the diagnosis on the parents and their consequent relationships with their child and their willingness to work with professionals is discussed.
\end{abstract}

Since Kanner's clinical account of 1943 there has been a growing interest in the pervasive developmental disorders of children, of which autism is the most well defined. ${ }^{1}$ Rutter has most clearly set out the current basic requirements for the diagnosis of this condition. ${ }^{2}$ Firstly, the onset of developmental impairment should be within the first 30 months of life. Secondly, there is a deviance of social relationships. Those that are formed are not appropriate to the child's mental age. Thirdly, autistic children have a wide range of abnormalities of communication. Fourthly, there are restricted, repetitive, stereotyped patterns of behaviour. In its classical form it is now readily recognised by experienced professionals.

More recently milder forms of these disorders have been described. Asperger's syndrome provides an example of this and Wing has delineated the characteristics of this condition. ${ }^{3}$ The affected individuals show a lack of empathy and have deviant styles of both verbal and nonverbal communication. They may embark upon long pedantic monologues on certain topics, with little emotional expression. They have constricted intellectual interests which may be to the exclusion of all else. Finally, they may show idiosyncratic attachment to inanimate objects. There are continuing debates as to whether these conditions are truly mild forms of autism or of some other type of disorder such as an early manifestation of schizoid personality. ${ }^{45}$ Whatever the answer to this the prognosis of these children is poor and the majority will, as adults, have major psychosocial difficulties.

These latter disorders are not common and they can be difficult for professionals to recognise. During a clincal interview the children can appear sociable and at times even desperate to form a relationship with the interviewer. Doctors and psychologists can fail to understand how emotionally draining it is to bring up such a child. The parents can be made to feel increasingly guilty that they have failed to meet their children's needs and may be blamed for difficulties that have been observed at school. A previous theory, now totally refuted, ${ }^{6}$ was that abnormalities in parenting were the direct cause of autism and the other developmental disorders. It is, however, almost certain that the cause is due to some form of brain dysfunction probably with a genetic basis, ${ }^{7}$ and indeed similar difficulties are often seen in other family members.

Over the last two years six children with Asperger's syndrome have been seen in a tertiary referral centre where previous workers have felt either the parents were fabricating the difficulties or that the children's behaviour was the result of emotional or sexual abuse. Only after admission did the nature of the behavioural abnormalities become clear. In most cases the parents' behaviour appeared at initial assessment to be either hostile, defensive, or even bizarre. Only as staff became able to empathise with their frustration at trying to cope with their child did their despair and isolation become apparent. A case history is presented of one such child and family and a table gives details of the remaining five.

\section{Case report}

A girl (case 1) was referred aged 10. Owing to her father's work the family had lived abroad a great deal. From age 18 months the mother had felt there was 'something wrong' with the girl, her first child. 'She never seemed to be really present: she didn't play like other children'. The worries grew when she compared her with her brother two years younger. The mother's fears were dismissed as 'neurotic' by a company doctor. At age 5 she started school; she was thought odd at the time and the term 'a rejected child' was used. An educational psychologist assessed her as having an intelligence quotient (IQ) of 85 and agreed with teachers that 'under an aloof exterior this was a child desperate for love'. The parents considered having psychiatric treatment for themselves. The father declined a promotion so that he could spend more time with the family. When the girl was aged 8 , a third child was born and the mother was concerned that the girl might harm the new baby. Both the general practitioner and the health visitor felt the girl had a normal interest in her 
Details of the six children

\begin{tabular}{|c|c|c|c|c|c|c|}
\hline $\begin{array}{l}\text { Case } \\
\text { No/sex }\end{array}$ & $\begin{array}{l}\text { Intellectual } \\
\text { quotient }\end{array}$ & $\begin{array}{l}\text { Neurological } \\
\text { deficit }\end{array}$ & $\begin{array}{l}\text { Development } \\
\text { difficulties }\end{array}$ & $\begin{array}{l}\text { Social difficulties } \\
\text { (child) }\end{array}$ & $\begin{array}{l}\text { Parental } \\
\text { history }\end{array}$ & $\begin{array}{l}\text { Social difficulties } \\
\text { (parents) }\end{array}$ \\
\hline $1 / \mathrm{F}$ & $\begin{array}{l}\text { Full scale } 60,{ }^{*} \\
\text { performance } 64, \\
\text { verbal } 60\end{array}$ & $\begin{array}{l}\text { EEG: normal, computed } \\
\text { tomogram: slightly } \\
\text { enlarged ventricles }\end{array}$ & $\begin{array}{l}\text { Language delay, } \\
\text { spelling difficulties }\end{array}$ & $\begin{array}{l}\text { Indiscriminate approaches } \\
\text { to adults. No concept of } \\
\text { friendship. Preoccupation } \\
\text { with violence to babies }\end{array}$ & $\begin{array}{l}\text { Father: managerial post, } \\
\text { mother: housewife }\end{array}$ & $\begin{array}{l}\text { Warm, appropriate care of } \\
\text { other children }\end{array}$ \\
\hline $2 / \mathbf{M}$ & $\begin{array}{l}\text { Full scale } 84, \\
\text { performance } 101, \\
\text { verbal } 72\end{array}$ & $\begin{array}{l}\text { EEG: generalised } \\
\text { dysfunctional types } \\
\text { non-specific. 'Clumsy' }\end{array}$ & Limited symbolic play & $\begin{array}{l}\text { Indiscriminate approaches } \\
\text { to adults. No concept of } \\
\text { interactive play. } \\
\text { Pronounced obsessional } \\
\text { traits }\end{array}$ & $\begin{array}{l}\text { Father: self employed } \\
\text { butcher, } \\
\text { mother: housewife }\end{array}$ & $\begin{array}{l}\text { Recurrent depressive } \\
\text { illness in mother }\end{array}$ \\
\hline $3 / M$ & $\begin{array}{l}\text { Full scale } 77, \\
\text { performance } 78, \\
\text { verbal } 79\end{array}$ & $\begin{array}{l}\text { EEG: normal, computed } \\
\text { tomogram: normal }\end{array}$ & $\begin{array}{l}\text { Visual and peripheral } \\
\text { memory deficit }\end{array}$ & $\begin{array}{l}\text { No concept of friendships. } \\
\text { No concept of interactive } \\
\text { play. Preoccupation with } \\
\text { fungi/insects }\end{array}$ & $\begin{array}{l}\text { Father: self employed } \\
\text { shop owner, mother: } \\
\text { housewife }\end{array}$ & $\begin{array}{l}\text { Marital discord. Mother } \\
\text { withdrawn, lacking friends } \\
\text { and socially isolated }\end{array}$ \\
\hline $4 / F$ & $\begin{array}{l}\text { Full scale } 71, \\
\text { performance } 71, \\
\text { verbal } 67\end{array}$ & $\begin{array}{l}\text { No neurological } \\
\text { deficits }\end{array}$ & Non-reader & $\begin{array}{l}\text { Indiscriminate relationship } \\
\text { with adults. No concept } \\
\text { of friendship. No concept } \\
\text { of play }\end{array}$ & $\begin{array}{l}\text { Father: car mechanic, } \\
\text { mother: housewife }\end{array}$ & $\begin{array}{l}\text { Father passive, suffered } \\
\text { depression. Mother cold, } \\
\text { affectionless with } \\
\text { institutional up bringing }\end{array}$ \\
\hline $5 / M$ & $\begin{array}{l}\text { Full scale } 89, \\
\text { performance } 87, \\
\text { verbal } 94\end{array}$ & $\begin{array}{l}\text { EEG: normal, computed } \\
\text { tomogram: normal }\end{array}$ & Language delay & $\begin{array}{l}\text { No concept of friendship. } \\
\text { No imaginative play. } \\
\text { Preoccupation with } \\
\text { ritualistic drawing }\end{array}$ & $\begin{array}{l}\text { Father: manual worker, } \\
\text { mother: housewife }\end{array}$ & $\begin{array}{l}\text { Father rubber fetishist. } \\
\text { Solitary, isolated } \\
\text { individual, pronounced } \\
\text { sexual fetishist. } \\
\text { Preoccupation with trains }\end{array}$ \\
\hline $6 / M$ & $\begin{array}{l}\text { Full scale } 138, \\
\text { performance } 130, \\
\text { verbal } 137\end{array}$ & EEG: normal & None & $\begin{array}{l}\text { No concept of friendship. } \\
\text { Preoccupation with } \\
\text { orderliness }\end{array}$ & $\begin{array}{l}\text { Father: sales } \\
\text { representative, } \\
\text { mother: shop assistant }\end{array}$ & $\begin{array}{l}\text { Father socially isolated. } \\
\text { Mother withdrawn with } \\
\text { history of drug/alcohol } \\
\text { abuse }\end{array}$ \\
\hline
\end{tabular}

*Please note discrepancy in quoted IQ scores which led to much investigation for organic brain deterioration, which was not later substantiated. EEG, electroencephalogram.

new sister. A total lack of educational progress led to a full assessment under the 1981 Education Act. The parents obtained a psychiatric opinion and referral to a child psychiatry inpatient unit was recommended.

On admission, she was a pale child and small for her age. On first contact she appeared to be highly sociable and well able to deal with social situations. She appeared to show a full range of normal emotions. It became readily apparent that these were learned behaviours and had no feeling or flexibility behind them. She had no concept of humour or of empathy. Her language in new situations was restricted and formal. Free play showed an obsession with babies and she would muse in a cold detached way about methods of killing them. Physical examination showed her height and weight on the 10th centile but no other abnormalities. A computed tomogram showed slightly enlarge ventricles but an electroencephalogram was normal. These features suggested Asperger's syndrome and it was thought that her apparent good social functioning was due to the enormous efforts made by her parents in their attempts to relate to her and enable her to cope with society. It was also thought that she had a definite potential of violence towards babies and a boarding school placement was recommended. Much work was needed to restore the parents' self esteem and to ensure that they would continue to offer all they could to their daughter.

Brief details of all six children are shown in the table. It can be seen that four of the six children were boys, a proportion that reflects the general excess of males with developmental disorders. All the children showed some evidence of impairment in the three main areas. In social abnormalities the majority showed a complete inability to understand other's feelings and had no concept of the meaning of abstract notions such as friendship or love. The communication difficulties ranged from a moderately stilted form of speech to grossly formalised almost robotic ways of communicating. The abnormal preoccupations ranged from an excessive amount of time being spent with a collection of toy cars to a child whose total day at school and at home was dominated by a preoccupation with fungi and the poisons that could be obtained from them (case 4). In all cases at least one professional with the power to make decisions affecting the child's life had formally recorded suspicions of abuse by the parents.

\section{Discussion}

These six cases shared many features. A superficial knowledge of each of the children would suggest a well functioning child whose emotional needs were somehow not being fully met. It required the experience of seeing the child in an inpatient unit before the full nature of the children's difficulties became apparent. Within days, staff would change their view from puzzlement at how the parents could complain about such a child to exasperation as the repetitive unrewarding nature of the interactions undermined the attempts by nursing staff to get to know their new patient. The parents had all been overwhelmed by guilt. They had all suggested that something had been very wrong but in all cases this had been dismissed by at least some of the professionals who had seen them. Three of the parents had considered that their child might be autistic and had read a great deal about the nature of the disorder. The unusual nature of their children's personalities and the feeling of an outsider or an observer living in the family led to extreme distress and parental behaviours that at times would appear bizarre. They had become very defensive towards professionals and suspicious in their dealings with 
them. In only one case did a parent have a history suggesting a full Asperger's syndrome, but he had played no part in caring for the child.

The key features the children demonstrated were a formal concrete way of thinking and an inability to identify and understand human emotions and relationships. Two of the children had worrying preoccupations with violence and death. In all cases the parents or foster parents were immensely relieved when a formal diagnosis was given to them even though they appreciated its prognostic significance. When their longstanding anxieties were acknowledged, all became willing and keen to work with staff for the good of their children. These histories point to the need to make formal mental state examinations of children. Four of the six had been seen previously by mental health professionals who had focused on family dynamics. Though these are of great importance they are not a substitute for a full psychiatric evaluation. With growing acceptance of the important concept of emotional abuse, in all these cases accusations that this was the cause of the problem had been made. In three cases formal case conferences had been held.
Despite these comments, children with even the most severe personality and developmental deviations can and do get abused emotionally, physically, and sexually. In any assessment of a non-functioning child the evaluation must include both family and social experiences and the child's own individual development and psychopathology. The milder forms of autism need to be recognised early so that parents can be helped to handle their unusual child and so that preventative work can be undertaken to stop severe behavioural problems being added to the underlying difficulty.

1 Kanner L Autistic disturbance of affective contact. Nervous Child 2:217-50.

2 Rutter $M$. Diagnosis and definition of childhood autism. f Autism Dev Disord 1978;8:139-61

3 Wing L. Asperger's syndrome: a clinical account. Psychol Med 1981;11:115-29.

4 Wolff S, Barlow A. Schizoid personality in childhood: a comparative study of schizoid, autistic and normal children. F Child Psychol Psychiatry 1979;20:29-46.

5 Wolff S, Urich J. Schizoid personality in childhood a controlled follow-up study. Psychol Med 1980;10:85-100.

6 Cantwell DP, Baker L, Rutter M. Family factors. In: Rutter M, Schopler E, eds. Autism: a reappraisal of concepts and treatment. New York: Plenum Press, 1978.

7 Folstein S, Rutter M. Infantile autism: a genetic study of 21 twin pairs. F Child Psychol Psychiatry 1977;18:297-321.

Brothers and sisters and the management of cerebral palsy Brothers and sisters are important. That the relationships between a handicapped child and his or her brothers and sisters may have important consequences seems self evident. Workers in Iowa (Martha Craft and colleagues, Developmental Medicine and Child Neurology 1990;32:1049-57) have tried to assess the effects of teaching siblings of children with cerebral palsy. They studied 15 children who had cerebral palsy and 16 normal siblings aged between 4 and 17 years. The normal siblings underwent a four month programme of education about the basic neurology of cerebral palsy and about motivational skills and ways of encouraging more independence in the handicapped child, the teaching being appropriate to the age of the sibling. After the programme the cerebral palsied children had increased ranges of movement in the joints of the upper limbs. Measures of self help skills showed no significant change, although the authors point to a 'trend' towards improvement and state that 'a few increases in functional status were dramatic'.

My enthusiasm for this work is cautious. Scientific assessment of management in cerebral palsy is notoriously difficult and anybody who tries it is to be encouraged. This study, however, is uncontrolled and the authors' enthusiasm for their own work is evident from their writing. They have shown some increase in joint mobility but no significant change in functional capacity. Reports of apparently dramatic changes in some patients are difficult to assess and can be produced by the practitioners of even the most obscure alternative therapies. It worries me too that they appear to give little consideration to the effect on the normal siblings. Their age range was wide and the implication seems to be that they all entered into things in a spirit of sibling love and altruism. Did none of them react against it or just get fed up? What will be the long term effects? It is important to avoid cynicism while at the same time preserving professionally detached judgment and trying to assess the validity and implications of the work. I'd like more information. 